\title{
STRATEGIC POSITIONING OF RURAL TOURISM ON STARA PLANINA
}

\author{
Gordana Petrović1, Mlađan Maksimović ${ }^{2}$ Darjan Karabaševićc ${ }^{3}$
}

\begin{abstract}
Stara Planina has excellent potential for rural tourism development which might be encountered in a small number of mountains in our country. Stara Planina possesses rich biological, geological and cultural heritage. Achieving visible economic effects requires set of activities, support and continuous monitoring of all government levels. By providing tourist services to domestic and foreign tourists, significant profit is made. Positive result realization of tourism economy depends on its ability to satisfy visitors needs in the chosen tourism destination. Hence, the aim of this paper is to introduce the strategic positioning of rural tourism as important activity in the field of tourism. In order to develop tourism in the best possible way, it is necessary to grasp the importance of strong economic growth of rural areas, so this paper thoroughly studies the respondents' opinion on the basis of ANOVA method and it tries to highlight the strategic directions of rural tourism development on Stara Planina.
\end{abstract}

Key words: Stara Planina, strategic positioning, tourism, rural tourism.

JEL: Q10, Z30, Z32, L83

\section{Introduction}

There are various definitions and interpretations of the notion tourism. There is no agreement upon one unique definition, and institutions as well as individuals differently interpret this notion. World Tourism Organization UNWTO defines tourism as "the activities of persons traveling to and staying in places outside their usual environment for not more than one consecutive year for leisure, business and other purposes" (http://

1 Gordana Petrović Ph.D., Geography teacher, Elementary school "Živadinka Divac" Kragujevac, Kralja Milutina Street nn, 34000, Kragujevac, Phone: +381 641892281 , E-mail: milicakg98@yahoo.com.

2 Mlađan Maksimović Ph.D., Independent researcher, Dr Zorana Đinđića Boulevard nn, 19000 Zaječar, Phone: +381 64 1479793, E-mail: mladjan21@yahoo.com.

3 Darjan Karabašević Ph.D., Assistant Professor, Faculty of Management, Economics and Finance, University Business Academy in Novi Sad, Jevrejska Street no. 24, 11000 Belgrade, Phone: +381 60 3383333, E-mail: darjankarabasevic@gmail.com.

EP 2017 (64) 2 (601-617) 
www.unwto.org). Therefore, the tourism, in the most general terms, could be defined as economic activity which includes persons' traveling outside the place of permanent residence for rest, fun and entertainment.

Tourism undoubtedly represents a significant segment of country's economic development due to its economical, sociological and ecological factor and which introduces immense changes in the environment (Cvijanovic et al., 2011). The tourism industry could be regarded as a branch which has the most dynamic development (Bahaee et al., 2014). In their research, Yu et al. (2011) and Kalaiya with Kumar (2015), particularly emphasize the importance of tourism for one country's economics, and they also insist on that tourism represents the source for development of local economics. Tourism, in general, could be seen as natural modification process because the proper understanding of this process enables the dynamics of tourism development, as well as the identification of main factors which influence the modifications in tourism development and choice of suitable strategies which, in turn, influence identification and evaluation during the planning of strategic directions for development of rural tourism (Streimikiene et al., 2015).

According to Mathieson and Wall (1982), tourism represents "the temporary movement of people to destinations outside their normal places of work and residence, and activities undertaken during their stay in those destinations..." Moreover, Goeldner and Ritchie (2007) believe that tourism represents "the sum of the phenomena and relationships arising from the interaction of tourists, business suppliers, host governments and host communities in the process of attracting and hosting these tourists and other visitors."

Chacko (1996) in his studies of enhancing attractiveness of tourism destinations in USA for the visitors from Japan especially highlights the importance of tourism destination positioning, while for positioning he claims that it represents the form of market communication which has the special role in expansion of tourism destination activity. Also, d'Angella and De Carlo (2016) point out in their research the importance of sustainability and strategic positioning of tourism destinations in order to achieve competitive advantage. Therefore, good positioning of tourism could be used as powerful mean for economic community development in rural areas and for further increasing of its prosperity. With good positioning of tourist product we can influence the consciousness of potential users (service user), in order to develop the positive image of specific product (destination), based on which the potential users would become loyal or so to say regular service users (Mustafa, 2009; Moutinho, 1989).

Stara Planina represents the space for rest and recreation, for both domestic and foreign tourists, so it is in other words very suitable for development as well as for the evaluation of rural tourism. It was proclaimed a nature reserve in 1997. It is an area with exceptional values when it comes to the diversity of flora and fauna and its communities, and geomorphological, geological and hydrological features. "The protection of nature represents such landscaping that in the greatest extent addresses the vital need of man, not only from the contemporary generation point of view but 
from the point of view of future generations and from the aspect of both current and long-term effects. Nature decoration is the part of thriving towards natural resource management and towards adequate assigned use of space. For the purposes of tourism, landscaping does not mean modification to such extent that the previous state could not be recognized" (Stankovic, Pavlovic, 2006). According to Spatial Plan of Republic of Serbia (2010-2020), Stara Planina as tourist area is classified in the group of destinations with year-round tourist offer.

"Nowadays, there are two perceptions of future economic development and use of space in Stara Planina nature reserve. Contrary to those who think about Stara Planina solely as a natural resource which at all cost has to be cashed, there are others (mostly nongovernmental organizations) who try to protect it or to adapt exploitation to its biodiversity" (Đorđević, Šušić, 2013).

As previously stated, the aim of this paper is to explore the importance and significance of rural tourism strategic positioning on Stara Planina as an essential condition for further social-economic development. Hence, the paper is structured in the following way: the first part represents introduction in which the basic tourism features are shown, the importance of tourism strategic positioning and basic characteristic and features of Stara Planina are presented, the second part illustrates literature review of rural tourism; the third part represents materials and research methods; the fourth part shows results and discussion of the conducted research; final part are concluding remarks given at the end of paper.

\section{Literature Review}

The tourist activities development in rural areas is rapid in the last few years. The society in which we live and which depends on information and communication technologies is the main reason which led man to develop a natural need to escape from technology world and to look for tranquility in the nature. It should be taken "into account the fact that tourists' needs quite difficult reach the point of complete satisfaction because it is always possible to visit a new tourist area and destination" (Bakić, 2008), so in that segment rural tourism is becoming more and more important. Singh (1999) interprets rural development as "process that leads to sustainable improvement in the quality of life of the rural people", and he also emphasizes that expanding rural non-agrarian sector creates possibilities for earning money and for population survival, and this particularly refers to the poor environments. Therefore, Lane (1994) rural tourism identifies with "smaller business which is founded in an open area in which there is an interaction with the world and nature, heritage and traditional features". Garrod et al. (2006) particularly point out rural tourism dependency on the broad specter of public and private ownership of natural and cultural resources, supporting infrastructure, as well as providing accommodation, food and beverage.

Rural Tourism is a significant component of integral and sustainable development and revitalization of village, as well as the missing component when it comes to the 
encouraging development of local market for agricultural and non-agricultural activities at the village, and also specifically when it comes to the encouraging employment (Todorović, Štetić, 2009). The goal of rural tourism development is to initiate recovery of rural area. There are real presuppositions for the goal fulfillment because rural areas have variety of natural, cultural and historic resources. With more dynamic program development guidance these potentials would represent a great base for rapid economic development of village. Rural tourism has great importance for economic development of Republic of Serbia; it represents source of income and employment. Rural area covers about $70 \%$ of territory of Serbia where lives about $43 \%$ of total population (Rural Development Strategy 2009-2013).

In the last few decades, rural tourism, as well as commercial tourism, go along with many environmental, social and cultural side effects, thus there is a need to shape this activity within concepts of sustainable development. Although the modern world is faced with responsibility and awareness that the planet must be persevered for present and future generations, it is necessary to balance human needs and nature conservation, because present generation has an obligation to leave at least as much chance as they had it for the future generation. Present generation has a right to use resources and healthy environment, but they cannot endanger the same right for the future generations (Marković, Pejanović, 2012; Jovičić, 2002).

Rural tourism could be useful for ecological environment sustainability because it imposes the reason for protection and preservation of natural habitats and wild animals precisely because of its value as a tourist resources, it increases tourists $\square$ awareness about environmental issues, it offers new infrastructure for tourism destination, as well as upgrade of existing infrastructure and it is a source of additional income for agricultural manufacturers. Contemporary approach to tourism destination is based on strategic planning which aim is to coordinate demands on tourist market and to maintain the balance between economic, social and ecological demands in accordance with the concept of sustainable development. Therefore, it is important to specify definition of sustainable tourism which was established by World Tourism Organization. World Tourism Organization (WTO) defines sustainable tourism as principle that on the one hand meets the need of tourists and need of tourism destination and on the other hand, it protects and increases tourist possibilities for the needs of future generation (http:// portal.unesco.org/es/files/45338/12417872579Introduction_Sustainable_Tourism.pdf/ Introduction_Sustainable_Tourism.pdf).

Ratknić and Milovanović (2016) think that sustainable development of rural areas in great extent depend on the application of combining concept "multifunctional agriculture", that is integral approach of overall improvement of life conditions with socio-economic status of rural communities, through increasing possibilities for employment outside agricultural activity but in accordance with available resources. In rural tourism destinations, rural tourism is not the main source of income. That is primarily agricultural activity, and tourism represents additional source of income in agricultural households. However, "it is founded that rural tourism can play a main 
role in diversification of the rural economy, and that as a mechanism can contribute to poverty reduction, improvement of quality of life, cultural heritage preservation and environment protection" (Master Plan for Sustainable Rural Tourism Development in Serbia, 2011). Cvijanović (2014) implies that rural tourism competes with other forms of tourist offer, so to say tourist product. He also highlights that Serbia possesses resources and capacities for rural tourism development which primarily should enable generating of additional income for farmers along with agriculture strengthening through product sale to tourists, as well as preventing the population migration, developing and strengthening infrastructure and also creating ethnic contents etc.

\section{Materials and Research Methods}

The aim of this paper is to examine the importance and significance of strategic directions of rural tourism development on Stara Planina. The research was conducted on the territory of several cities in Eastern Serbia (Knjaževac, Zaječar and Pirot) in the period from $15 / 07 / 2016$ to $15 / 10 / 2016$. The survey instrument was questionnaire. The survey was anonymous and the total number of 380 questionnaires was distributed. The number of correctly filled questionnaires was 300, which represents $78,94 \%$ of respondents. The level of response rate and correctly filled questionnaires was expected and it is in correspondence with results that were recommended in the literature (Das et al., 2000; Kayank, 2003; Molina et al., 2007). In specially prepared questionnaire, the following strategic directions are proposed: production of general touristic offer; creation of such touristic offer which would enable wide range of different content to tourist in order to satisfy their desires and needs; using aggressive marketing, advertising and market performances to set the goal so that public or so to say domestic and foreign tourists acquaint with exceptional beauties and possibilities that rural tourism of Stara Planina offers; better use of favorable geographical position of Stara Planina; recognizing the importance of rural tourism as a possible mean for integral and sustainable development of village and rural areas, but also as a possible brand on international tourism market; and environmental protection.

The five-point Likert scale was used for the gradation of obtained responses, and result processing was performed via software package SPSS 23.0. Statistical method ANOVA (Analysis of Variance) was applied in order to examine the differences of one or more independent variable and one dependent variable, or precisely in this case, to detect differences in respondents' responses in relation to their demographical data such as: respondent category, current place of residence, position in the organization and if it exists whether this difference is statistically significant. Tukey-Snedecor "post hoc" test is applied in order to calculate the critical difference, or so to say to determine in which responses marked variations could be found.

\section{Discussion and research results}

Importance and significance of strategic directions of rural tourism development on Stara Planina are displayed in the following tables and graphs.

EP 2017 (64) 2 (601-617) 
Table 1. Descriptive analysis of importance and significance of strategic directions of rural tourism development on Strana Planina based on the respondents' professions

\begin{tabular}{|c|c|c|c|c|c|c|c|c|}
\hline & \multirow{2}{*}{$\mathbf{N}$} & \multirow{2}{*}{ Average } & \multirow{2}{*}{$\begin{array}{c}\text { Std. } \\
\text { Deviation }\end{array}$} & \multirow{2}{*}{ Std. error } & \multicolumn{2}{|c|}{$\begin{array}{c}95 \% \text { average } \\
\text { interval }\end{array}$} & \multirow{2}{*}{ Minimum } & \multirow{2}{*}{ Maximum } \\
\hline & & & & & law & upper & & \\
\hline Student & 18 & 3.8333 & 0.98020 & 0.23103 & 3.3459 & 4.3208 & 1.50 & 5.00 \\
\hline Empoyed & 232 & 4.3626 & 0.66002 & 0.04333 & 4.2773 & 4.4480 & 1.50 & 5.00 \\
\hline Unempoyed & 30 & 3.5333 & 1.13495 & 0.20721 & 3.1095 & 3.9571 & 1.50 & 4.83 \\
\hline $\begin{array}{l}\text { Agricultural } \\
\text { manufacturer }\end{array}$ & 6 & 4.4444 & 0.17213 & 0.07027 & 4.2638 & 4.6251 & 4.33 & 4.67 \\
\hline Retiree & 14 & 4.4524 & 0.48670 & 0.13008 & 4.1714 & 4.7334 & 3.67 & 5.00 \\
\hline Total & 300 & 4.2538 & 0.77550 & 0.04477 & 4.1657 & 4.3419 & 1.50 & 5.00 \\
\hline
\end{tabular}

Source: Author's calculation based on the survey data

When it comes to the evaluation of importance and significance of strategic directions of rural tourism development on Stara Planina, based on the respondent profession (Table 1) the highest average grades gave the retirees (4.4524), and the lowest average grades gave unemployed respondents (3.5333).

Bearing in mind that there are deviations on the level of the average, the methodology itself directs us towards examination of average values for given group of questions. For this sort of data, the most suitable is analysis of variance with which would be possible to determine whether there are differences in importance and significance evaluation of strategic directions of rural tourism development on Stara Planina between the groups and whether there are differences in responses within the group.

Table 2. Analysis of variance for importance and significance of strategic directions of rural toruism development on Stara Planina based on respondent profession

\begin{tabular}{|l|c|c|c|c|c|}
\hline & The sum of squares & Df - test & $\begin{array}{c}\text { Average } \\
\text { squares }\end{array}$ & f-test & $\begin{array}{c}\text { Probability of } \\
\text { error }\end{array}$ \\
\hline Between Groups & 22.273 & 4 & 5.568 & 10.426 & 0.000 \\
\hline Within Groups & 157.546 & 295 & 0.534 & & \\
\hline Total & 179.819 & 299 & & & \\
\hline
\end{tabular}

Source: Author's calculation based on the survey data

In the Table 2 the following values are displayed: the sum of squares between the groups is 22.273, average squares between the groups is 5.568 total, the sum of squares within the group is 157.546 , average squares within the group is 0.534 . Value of f-test is equal to 10.426 and this value is then compared to cutoff value of f-test (from the average values table). Error probability which is $0.00 \%$ indicates that the respondents' answers differ 
within the group and between the groups. Based on these indicators, we use post hoc test in order to determine in which response could be found market variation.

Table 3. Post Hoc test for importance and significance of strategic directions of rural tourism development on Stara Planina based on the respondent profession

\begin{tabular}{|c|c|c|c|c|c|c|}
\hline \multirow{2}{*}{\multicolumn{2}{|c|}{ Category of respondents: }} & \multirow{3}{*}{$\begin{array}{r}\begin{array}{c}\text { Average } \\
\text { difference }\end{array} \\
-0.52931\end{array}$} & \multirow{3}{*}{\begin{tabular}{|r|}
\multicolumn{1}{l}{$\begin{array}{l}\text { Standard } \\
\text { error }\end{array}$} \\
0.17881
\end{tabular}} & \multirow{3}{*}{\begin{tabular}{|r|}
$\begin{array}{c}\text { Probability of } \\
\text { error } \\
\text { low }\end{array}$ \\
0.027
\end{tabular}} & \multicolumn{2}{|c|}{$95 \%$ average interval } \\
\hline & & & & & upper & \\
\hline \multirow{4}{*}{ Student } & Employed & & & & -1.0201 & -0.0385 \\
\hline & Unemployed & 0.30000 & 0.21788 & 0.643 & -0.2980 & 0.8980 \\
\hline & $\begin{array}{l}\text { Agricultural } \\
\text { manufacturer }\end{array}$ & -0.61111 & 0.34450 & 0.391 & -1.5567 & 0.3344 \\
\hline & Retiree & -0.61905 & 0.26042 & 0.124 & -1.3338 & 0.0957 \\
\hline \multirow{4}{*}{ Employed } & Student & 0.52931 & 0.17881 & 0.027 & 0.0385 & 1.0201 \\
\hline & Unemployed & 0.82931 & 0.14179 & 0.000 & 0.4401 & 1.2185 \\
\hline & $\begin{array}{l}\text { Agricultural } \\
\text { manufacturer }\end{array}$ & -0.08180 & 0.30218 & 0.999 & -0.9112 & 0.7476 \\
\hline & Retiree & 0.08974 & 0.20112 & 0.992 & -0.6418 & 0.4623 \\
\hline \multirow{4}{*}{ Unemployed } & Student & -0.30000 & 0.21788 & 0.643 & -0.8980 & 0.2980 \\
\hline & Employed & -0.82931 & 0.14179 & 0.000 & -1.2185 & -0.4401 \\
\hline & $\begin{array}{l}\text { Agricultural } \\
\text { manufacturer }\end{array}$ & -0.91111 & 0.32682 & 0.044 & -1.8081 & -0.0141 \\
\hline & Retiree & -0.91905 & 0.23653 & 0.001 & -1.5683 & -0.2698 \\
\hline \multirow{4}{*}{$\begin{array}{l}\text { Agricultural } \\
\text { manufacturer }\end{array}$} & Student & 0.61111 & 0.34450 & 0.391 & -0.3344 & 1.5567 \\
\hline & Employed & 0.08180 & 0.30218 & 0.999 & -0.7476 & 0.9112 \\
\hline & Unemployed & 0.91111 & 0.32682 & 0.044 & 0.0141 & 1.8081 \\
\hline & Retiree & -0.00794 & 0.35659 & 1.000 & -0.9867 & 0.9708 \\
\hline \multirow{4}{*}{ Retiree } & Student & 0.61905 & 0.26042 & 0.124 & -0.0957 & 1.3338 \\
\hline & Employed & 0.08974 & 0.20112 & 0.992 & -0.4623 & 0.6418 \\
\hline & Unemployed & 0.91905 & 0.23653 & 0.001 & 0.2698 & 1.5683 \\
\hline & $\begin{array}{l}\text { Agricultural } \\
\text { manufacturer }\end{array}$ & 0.00794 & 0.35659 & 1.000 & -0.9708 & 0.9867 \\
\hline
\end{tabular}

Source: Author's calculation based on the survey data

The average rate for importance and significance of strategic directions of rural tourism development on Stara Planina (Table 3) displays that grades given by students and employed are statistically different with the probability of error 0.027 where $\mathrm{p}<0.05$. Analysis results indicate that respondents who are employed gave high average grades 
and they entirely agreed that strategic directions of rural tourism development on Stara Planina are important and significant. Also, significant statistical distinction in evaluating importance and significance of strategic directions of rural tourism development on Stara Planina could be noticed when it comes to the employed and unemployed respondents with the probability for error 0.000 where $\mathrm{p}<0.05$. That indicates that employed respondents in contrast with those who were unemployed gave much higher average grades for importance and significance of strategic directions of rural tourism development on Stara Planina. Moreover, significant statistical difference in the answers of agricultural manufacturers and unemployed respondents is noticed with the probability for error 0.044 where $\mathrm{p}<0.05$, which indicates that agricultural manufacturers in contrast with unemployed respondents gave much higher average grades for importance and significance of strategic directions of rural tourism development on Stara Planina. Statistically significant differences could be noted in answers of retirees and unemployed respondents with probability for error 0.001 where $\mathrm{p}<0.05$. That suggests that retirees in contrast with unemployed respondents gave much higher average grades for strategic directions of rural tourism development on Stara Planina.

Figure 1. Average values diagram of grades for importance and significance of strategic directions of rural tourism development on Stara Planina

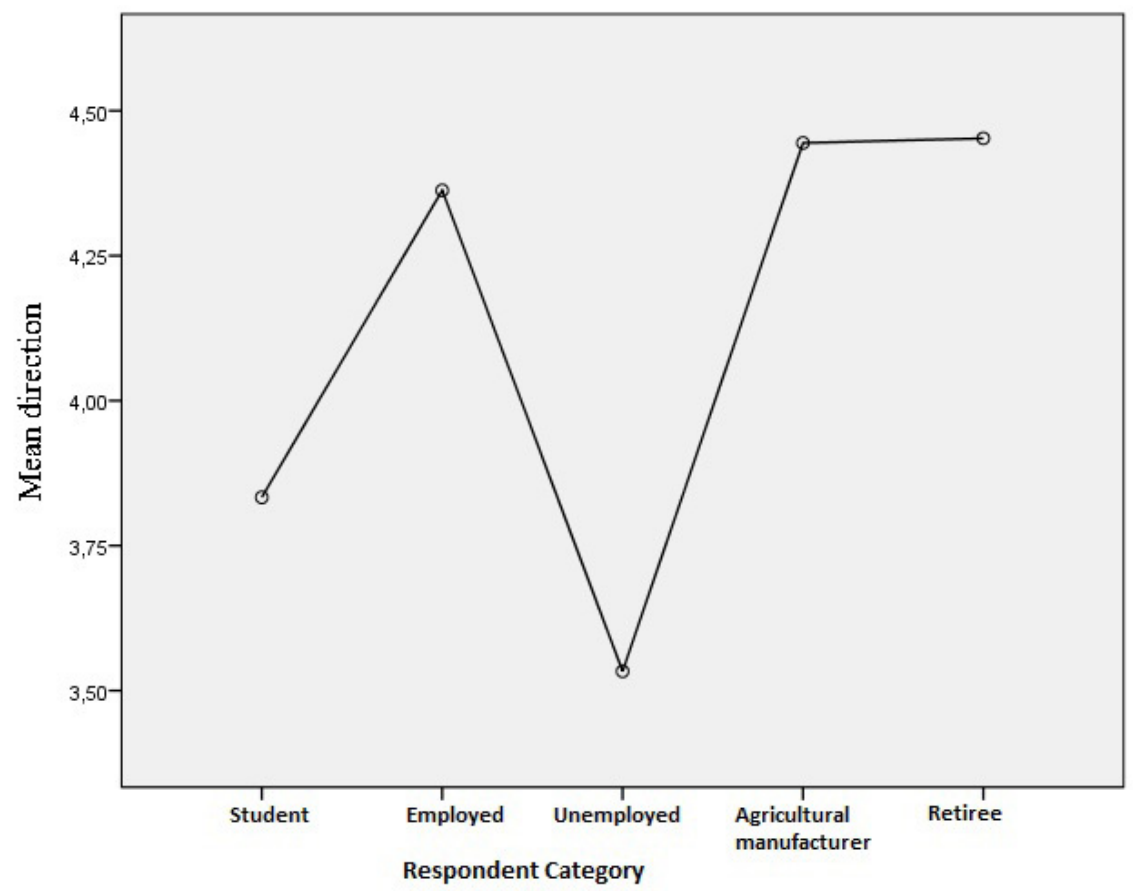

Source: Author's calculation based on the survey data

Average values diagram of evaluation of importance and significance of strategic directions of rural tourism development on Stara Planina (Figure 1) specifically indicates that students and unemployed respondents gave the lowest average grades while employed 
respondents, agricultural manufacturers and retirees gave high average grades.

Table 4. Descriptive analisys of importance and significance of strategic directions of rural torusim development on Stara Planina based on the repondent position in the organization.

\begin{tabular}{|c|c|c|c|c|c|c|c|c|}
\hline & \multirow{2}{*}{$\mathbf{N}$} & \multirow{2}{*}{ Average } & \multirow{2}{*}{$\begin{array}{c}\text { Std. } \\
\text { Deviation }\end{array}$} & \multirow{2}{*}{ Std. error } & \multicolumn{2}{|c|}{$\begin{array}{l}95 \% \text { average } \\
\text { interval }\end{array}$} & \multirow{2}{*}{ Minimum } & \multirow{2}{*}{ Maximum } \\
\hline & & & & & low & upper & & \\
\hline $\begin{array}{l}\text { Local } \\
\text { government }\end{array}$ & 76 & 4.1509 & 0.89500 & 0.10266 & 3.9464 & 4.3554 & 1.50 & 5.00 \\
\hline $\begin{array}{l}\text { Hospitality } \\
\text { and Tourism } \\
\text { Sector }\end{array}$ & 120 & 4.4306 & 0.63825 & 0.05826 & 4.3152 & 4.5459 & 1.50 & 5.00 \\
\hline Other & 58 & 4.2989 & 0.52497 & 0.06893 & 4.1608 & 4.4369 & 3.00 & 5.00 \\
\hline Total & 254 & 4.3168 & 0.71108 & 0.04462 & 4.2289 & 4.4047 & 1.50 & 5.00 \\
\hline
\end{tabular}

Source: Author's calculation based on the survey data

When it comes to the assessment of importance and significance of strategic directions of rural tourism development on Stara Planina based on the respondent position in the organization (Table 4) the highest average grade was given by respondents who were employed in the hospitality and tourism sector (4.4306), and the lowest average grade was given by those employed in local government (4.1509).

Table 5. Analysis of variance for importance and significance of strategic directions of rural torusim development on Stara Planina

\begin{tabular}{|l|c|c|c|c|c|}
\hline & The sum of squares & Df - test & $\begin{array}{c}\text { Average } \\
\text { squares }\end{array}$ & f-test & $\begin{array}{c}\text { Probability for } \\
\text { error }\end{array}$ \\
\hline Between Groups & 3.664 & 2 & 1.832 & 3.700 & 0.026 \\
\hline Within Groups & 124.262 & 251 & 0.495 & & \\
\hline Total & 127.926 & 253 & & & \\
\hline
\end{tabular}

Source: Author's calculation based on the survey data

Based on the data (Table 5) collected via ANOVA test, we can conclude that responses of previously mentioned groups differ between groups, as well as, within the group itself. Because of these indicators we approached to analysis of Post Hoc test in order to determine in which responses the biggest deviation was made. 
Table 6. Results of Post Hoc test for examined variance of importance and significance of strategic directions of rural torusim development on Stara Planina

\begin{tabular}{|c|c|c|c|c|c|c|}
\hline \multirow{2}{*}{\multicolumn{2}{|c|}{$\begin{array}{c}\text { Respondents' position in the } \\
\text { organization }\end{array}$}} & \multirow{3}{*}{$\begin{array}{c}\begin{array}{c}\text { Average } \\
\text { difference }\end{array} \\
-0.27968\end{array}$} & \multirow{3}{*}{$\begin{array}{r}\text { Std. error } \\
0.10315\end{array}$} & \multirow{3}{*}{$\begin{array}{c}\begin{array}{c}\text { Probability for } \\
\text { error } \\
\text { low }\end{array} \\
0.020 \\
\end{array}$} & \multicolumn{2}{|c|}{$95 \%$ average interval } \\
\hline & & & & & \multirow{2}{*}{$\begin{array}{l}\text { upper } \\
-0.5229\end{array}$} & \multirow[b]{2}{*}{-0.0365} \\
\hline Local & \begin{tabular}{|l|}
$\begin{array}{l}\text { Hospitality and } \\
\text { tourism sector }\end{array}$ \\
\end{tabular} & & & & & \\
\hline government & Other & -0.14797 & 0.12268 & 0.451 & -0.4372 & 0.1413 \\
\hline \multirow{2}{*}{$\begin{array}{l}\text { Hospitality and } \\
\text { tourism sector }\end{array}$} & \begin{tabular}{|l}
$\begin{array}{l}\text { Local } \\
\text { government }\end{array}$ \\
\end{tabular} & 0.27968 & 0.10315 & 0.020 & 0.0365 & 0.5229 \\
\hline & Other & 0.13170 & 0.11252 & 0.472 & -0.1336 & 0.3970 \\
\hline \multirow{2}{*}{ Other } & $\begin{array}{l}\begin{array}{l}\text { Local } \\
\text { government }\end{array} \\
\end{array}$ & 0.14797 & 0.12268 & 0.451 & -0.1413 & 0.4372 \\
\hline & $\begin{array}{l}\text { Hospitality and } \\
\text { tourism sector }\end{array}$ & -0.13170 & 0.11252 & 0.472 & -0.3970 & 0.1336 \\
\hline
\end{tabular}

Source: Author's calculation based on the survey data

Post Hoc test results (Table 6) shows that the average grades for importance and significance of strategic directions of rural tourism development on Stara Planina statistically differ when it comes to the employed in local government and employed in hospitality and tourism sector, with zero probability for error 0.020 . This indicates that respondents employed in the hospitality and tourism sector gave much higher average grades and that they completely agreed that the strategic directions of rural tourism development on Stara Planina was important and significant for setting up new development vision and strategic goals which they would strive to fulfill. Also, there are significant statistical differences in assessment of importance and significance of strategic directions of rural tourism development on Stara Plaina between employed in hospitality and tourism sector and employed in other sectors (traffic, cultural, agricultural...). Respondents employed in local government gave specifically low average grades for importance and significance of strategic directions of rural tourism development on Stara Planina and they did not agree with development. 
Figure 2. Average values diagram of grades for importance and significance of strategic directions of rural tourism development on Stara Planina based on the respondent postition in the organization

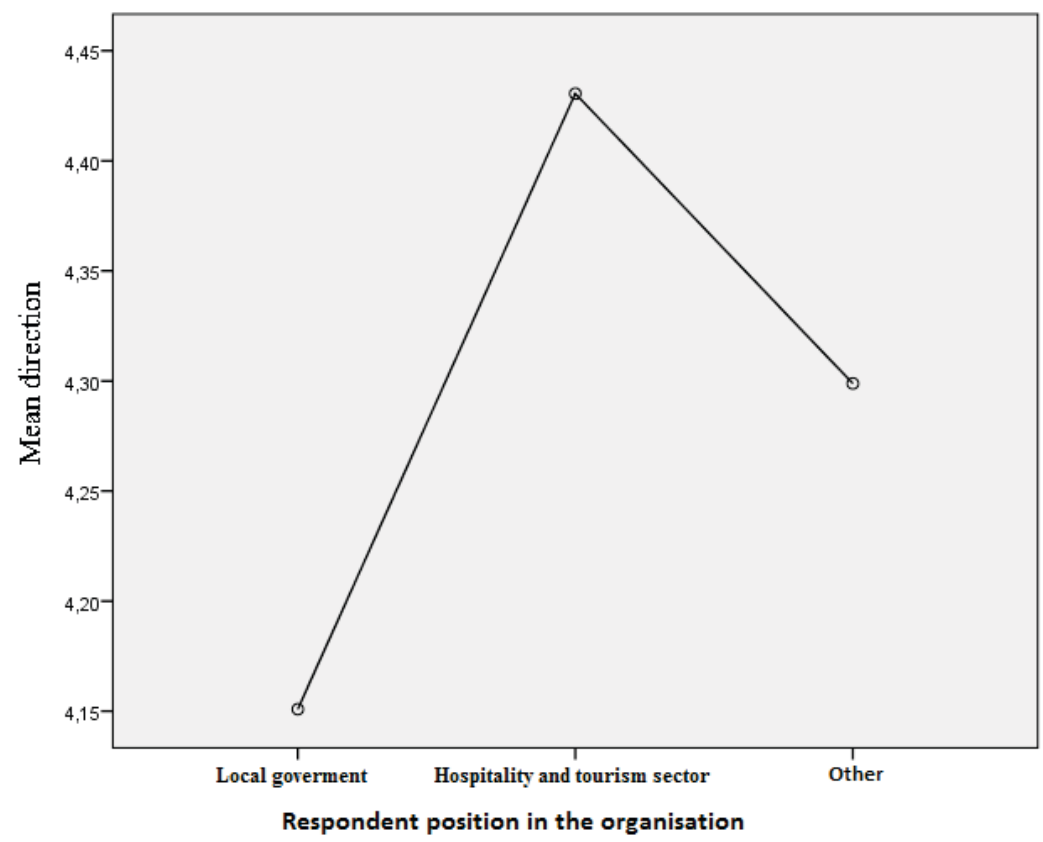

Source: Author's calculation based on the survey data

Average values diagram of evaluating importance and significance of strategic directions of rural tourism development on Stara Planina (Figure 2) unambiguously indicates that respondents employed in hospitality and tourism sector gave high average grades, and respondetns employed in local government and in other sectors gave very low average grades.

Table 7. Descriptive analysis of importance and significance of strategic directions of rural tourism development on Stara Planina based on the place of residence

\begin{tabular}{|c|c|c|c|c|c|c|c|c|}
\hline & \multirow[t]{2}{*}{$\mathbf{N}$} & \multirow[t]{2}{*}{ Average } & \multirow{2}{*}{$\begin{array}{c}\text { Std. } \\
\text { Deviation }\end{array}$} & \multirow[t]{2}{*}{ Std. error } & \multicolumn{2}{|c|}{$\begin{array}{c}95 \% \text { average } \\
\text { interval }\end{array}$} & \multirow[t]{2}{*}{ Minimum } & \multirow[t]{2}{*}{ Maximum } \\
\hline & & & & & low & upper & & \\
\hline $\begin{array}{l}\text { Municipality } \\
\text { of Knjazevac }\end{array}$ & 109 & 4.2000 & 0.78863 & 0.07554 & 4.0503 & 4.3497 & 1.50 & 5.00 \\
\hline $\begin{array}{l}\text { Municipality } \\
\text { of Zajecar }\end{array}$ & 120 & 4.2750 & 0.83784 & 0.07648 & 4.1236 & 4.4264 & 1.50 & 5.00 \\
\hline $\begin{array}{l}\text { Municipality } \\
\text { of Pirot }\end{array}$ & 71 & 4.3005 & 0.63908 & 0.07585 & 4.1492 & 4.4517 & 1.50 & 5.00 \\
\hline Total & 300 & 4.2538 & 0.77550 & 0.04477 & 4.1657 & 4.3419 & 1.50 & 5.00 \\
\hline
\end{tabular}

Source: Author's calculation based on the survey data 
When it comes to the grade of importance and significance of strategic directions of rural tourism development on Stara Planina based on the respondent residence place (Table 7 ) it could be concluded that the highest grade was given by residents of Municipality of Pirot (4.3005), and the lowest average grade was given by respondents who lived in Municipality of Knjaževac (4.2000).

Table 8. Analysis of variance for importance and significance of strategic directions of rural tourism development on Stara Planina based on the place of residence

\begin{tabular}{|l|c|c|c|c|c|}
\hline & $\begin{array}{c}\text { The sum of } \\
\text { squares }\end{array}$ & Df - test & $\begin{array}{c}\text { Average } \\
\text { squares }\end{array}$ & f-test & $\begin{array}{c}\text { Probability for } \\
\text { error }\end{array}$ \\
\hline Between Groups & 0.524 & 2 & 0.262 & 0.434 & 0.648 \\
\hline Within Groups & 179.295 & 297 & 0.604 & & \\
\hline Total & 179.819 & 299 & & & \\
\hline
\end{tabular}

Source: Author's calculation based on the survey data

Results of ANOVA test (Table 8) shows the sum of squares between groups and average squares between groups, along with the values of $f$ test $(0,434)$, which is compared with cutoff value for $f$ that is taken from the table of cutoff values. With minimal error possibility, it could be concluded that respondents' answers differ within the group and between groups. In order to determine the highest deviation in respondents' answers, we used analysis of Post Hoc test.

Table 9. Results of Post Hoc test for examined variance of importance and significance of strategic directions of rural torusim development on Stara Planina

\begin{tabular}{|c|c|c|c|c|c|c|}
\hline & & Average & & Probability for & $95 \%$ averag & nterval \\
\hline & & difference & & & unner. & \\
\hline Municipality of & $\begin{array}{l}\text { Municipality of } \\
\text { Zajecar }\end{array}$ & -0.07500 & 0.10281 & 0.746 & -0.3172 & 0.1672 \\
\hline Knjazevac & $\begin{array}{l}\text { Municipality of } \\
\text { Pirot }\end{array}$ & -0.10047 & 0.11849 & 0.674 & -0.3796 & 0.1786 \\
\hline Municipality of & $\begin{array}{l}\text { Municipality of } \\
\text { Knjazevac }\end{array}$ & 0.07500 & 0.10281 & 0.746 & -0.1672 & 0.3172 \\
\hline Zajecar & $\begin{array}{l}\text { Municipality of } \\
\text { Pirot }\end{array}$ & -0.02547 & 0.11633 & 0.974 & -0.2995 & 0.2486 \\
\hline Municipality of & $\begin{array}{l}\text { Municipality of } \\
\text { Knjazevac }\end{array}$ & 0.10047 & 0.11849 & 0.674 & -0.1786 & 0.3796 \\
\hline Pirot & $\begin{array}{l}\text { Municipality of } \\
\text { Zajecar }\end{array}$ & 0.02547 & 0.11633 & 0.974 & -0.2486 & 0.2995 \\
\hline
\end{tabular}

Source: Author's calculation based on the survey data

Since the area of Stara Planina covers territories of Municipality of Zaječar, Knjaževac, Pirot and Dimitrovgrad, residents who lived in these three municipalities were surveyed. Table 9 displays differences in responses between respondents of chosen municipalities, but these differences are statistically insignificant. 
Figure 3. Average values diagram of grades for importance and significance of strategic directions of rural tourism development on Stara Planina based on the respondent place of residence

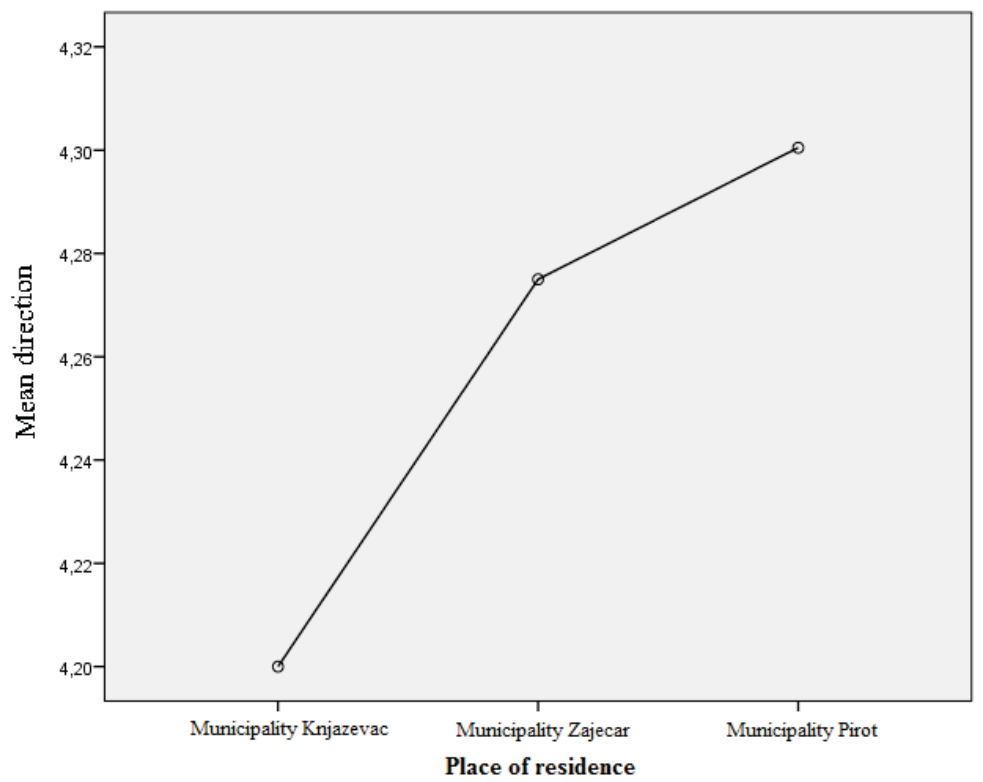

Source: Author's calculation based on the survey data

On average values diagram of evaluating importance and significance of strategic directions of rural tourism development on Stara Planina based on the respondent place of residence (Figure 3) particularly could be noted that residents of Municipality of Pirot gave the highest average grades, and respondents of Municipality of Knjaževac gave the lowest average grades for importance and significance of strategic directions of rural tourism development on Stara Planina. As already has been said, the differences in their responses are statistically insignificant.

Rural tourism development is very complex and long term work. Understanding the needs of the locals, as well as their aspirations and habits, customs and financial status, contributes to the best development of rural tourism. Development activities, along with the quality and professional program for rural tourism development can contribute to the development of rural areas (Maksimović et al., 2015). Agriculture still is the main activity of rural areas. However, the structural economic change should go towards development of other branches of economy. Primarily, the goal we should strive to is the rural tourism development on Stara Planina. Apart from the importance which rural tourism destination receives through the development of this economic branch, development of other economic activities would be encouraged. 


\section{Conclusion}

Contemporary tourist market is in constant search for new ways and forms of spending free time. Mass or commercial tourism has reached the point of saturation, when it comes to the tourist demand as well as offer. Therefore, the development of tourist activities in rural areas is considerably faster in the last few years. People dependence on information and communication technologies make the man to leave the technology world and find his serenity in the nature. Rural tourism development does not only mean the development of tourism in one specific area, but further development of neighboring geographical areas as well, thus providing their tourist valorization. Rural tourism, as this research confirmed, unambiguously contributes the preservation of nature and cultural and historical heritage, it also prevents migrations from so called "passive" areas and thus it encourages revalorization of indigenous values of specific areas.

Conducted survey research indicates that there are statistically significant distinctions between specific respondents groups and within a group itself. Certain respondents (unemployed, students, employed in other activity sectors and residents of Municipality of Knjaževac) showed insufficient knowledge about rural tourism significance for economic development of undeveloped areas. They did not recognize the importance and strategic positioning mechanism for rural tourism on Stara Plana which could initiate the process of poverty reduction in rural areas. The importance of rural tourism in rural areas was recognized by those who were directly related with it, which is indicated with survey results (employed residents, agricultural manufacturers, retirees, hospitality and tourism sector employees and residents of Municipality of Pirot). Rural tourism development could contribute to socio-economic development of rural areas, especially if we approach to rural areas development strategically in respect to the concept of sustainable development. The successful development of rural tourism contributes to increasing of effective source of additional income and unemployment reducing, especially in peripheral rural areas on Stara Planina. It is obvious that development of rural tourism and other forms of tourism on Stara Planina contributes to more balanced development, self-employment and motivation of young people to stay at village, and in great extent it influences the preservation of local area identity, its customs and traditions.

Regardless of recorded increase in number of tourists in rural tourism, it could be said that it develops extremely slowly. It is often faced with the insufficient demand despite the great wealth of natural spaces and cultural and historical heritage. In order to expect a further growth and development, the support of many factors is necessary; on the first place help from the state and local community in the process for offer renovation and expansion, then increasing of demand and training of people are needed. For application of adequate management model it is necessary to examine the potential of Stara Planina and to find the way for their quality valorization. For strategic positioning of tourism on Stara Planina, it is important to give a clear guidelines and to open a new space for rural tourism development in the period which is coming, and which is based on the principles of responsible and sustainable development. 


\section{Literature}

1. Bahaee, M., Pisani, M. J., Shavakh, F. (2014). Residents' attitudes toward international tourism: A case of Iran. Journal of Tourism and Recreation, Vol. 1, No. 2, pp.1-14.

2. Bakić, O. (2008). Marketing u turizmu. Fakultet za uslužni biznis, Novi Sad.

3. Chacko, H. E. (1996). Positioning a tourism destination to gain a competitive edge. Asia Pacific Journal of Tourism Research, Vol. 1, No. 2, pp. 69-75.

4. Cvijanović, D. (2014). Turističko tržište u dunavskom region. Institut za ekonomiku poljoprivrede, Monografija, Beograd.

5. Cvijanović, D., Vuković, P., Kljajić, N. (2011). Stanje i perspektive razvoja ruralnog turizma u Republici Srbiji. VI Međunarodni naučni skup "Mediteranski dani Trebinje -TURIZAM I RURALNI RAZVOJ”- savremene tendencije, problemi i mogućnosti razvoja, pp. 11-21.

6. d'Angella, F., De Carlo, M. (2016). Orientation to sustainability and strategic positioning of destinations: an analysis of international tourism websites. Current Issues in Tourism, Vol. 19, No. 7, pp. 624-633.

7. Das, A., Handfield, R. B., Calantone, R. J., Ghosh, S. (2000). A contingent view of quality management - the impact of international competition on quality. Decision Sciences, Vol. 31, No. 3, pp. 649-690.

8. Đorđević, D. Ž., Šušić, V. (2013). Turistički centar na Staroj planini-ekološki ili ekonomski neuspeh?. Teme, No. 1, pp. 459-478.

9. Garrod, B., Wornell, R., Youell, R. (2006). Re-conceptualising rural resources as countryside capital: The case of rural tourism. Journal of rural studies, Vol. 22, No.1, pp. 117-128.

10. Goeldner, C. R., Ritchie, J. B. (2007). Tourism principles, practices, philosophies. John Wiley \& Sons.

11. http://portal.unesco.org/es/files/45338/12417872579Introduction_Sustainable Tourism.pdf/Introduction_Sustainable Tourism.pdf

12. http://www.unwto.org

13. Jovičić, D. (2002). Menadžment turističkih destinacija, Želnid, Beograd.

14. Kalaiya, A. B., Kumar, A. (2015). Tourism as a development tool: A study on role of tourism in economic development, employment generation and poverty reduction: Special focus on Kachchh. International Journal, Vol. 3, No. 7, pp. 189-197.

15. Kaynak, H. (2003). The relationship between total quality management practices and their effects on firm performance. Journal of operations management, Vol. 21, No. 4, pp. 405-435.

16. Lane, B. (1994). What is rural tourism? Journal of sustainable tourism, Vol. 2, No. (1-2), pp. 7-21.

17. Maksimović, M., Urošević, S., Mihajlović, D. (2015). The effects of the development 
of rural tourism on Stara Planina. Ekonomika, Vol. 61, No. 2, pp. 83-92.

18. Marković, S., Pejanović, Lj. (2012). Zaštita životne stedine u politici održivog razvoja. Fakultet za pravne i poslovne studije, Novi Sad.

19. Master plan održivog razvoja ruralnog turizma u Srbiji, Beograd 2011.

20. Mathieson, A., Wall, G. (1982). Tourism, economic, physical and social impacts. Longman.

21. Ministarstvo poljoprivrede, šumarstva i vodoprivrede (2008). Plan strategije ruralnog razvoja 2009-2013.

22. Molina, L. M., Lloréns-Montes, J., Ruiz-Moreno, A. (2007). Relationship between quality management practices and knowledge transfer. Journal of Operations Management, Vol. 25, No. 3, pp. 682-701.

23. Moutinho, L. (1989). Tourism positioning strategies. Prentice Hall. pp. 541-544

24. Mustafa, K. (2009). Product positioning strategy in marketing management. Journal of Naval Science and Engineering, Vol. 5, No. 2, pp. 98-110.

25. Ratknic, T., Milovanovic, J. (2016). Medicinal herbs as part of the development of sustainable tourism in nature park "Stara planina". Ekonomika Poljoprivrede, Vol. 63, No. 3, pp. 847-860.

26. Republika Srbija (2010). Prostorni plan Republike Srbije od 2010 do 2020 godine.

27. Singh, K. (2009). Rural development: principles, policies and management. Sage Publications.

28. Stanković, S., Pavlović, S. (2006). Savremeni turizam i prostor. Geografski fakultet Univerziteta u Beogradu, No. 54.

29. Streimikiene, D., Bilan, Y. (2015). Review of rural tourism development theories. Transformations in Business \& Economics, Vol. 14, No. 2, pp. 21-34.

30. Todorović, M., Štetić, S. (2009). Ruralni turizam. Geografski fakultet Univerziteta u Beogradu, Beograd.

31. Yu, C. P., Charles Chancellor, H., Tian Cole, S. (2011). Examining the effects of tourism impacts on resident quality of life: evidence from rural midwestern communities in USA. International Journal of Tourism Sciences, Vol. 11, No. 2, pp. 161-186. 


\title{
STRATEGIJSKO POZICIONIRANJE RURALNOG TURIZMA STARE PLANINE
}

\section{Gordana Petrovićc ${ }^{4}$ Mlađan Maksimovičc, Darjan Karabaševićc}

\begin{abstract}
Apstrakt
Stara planina poseduje odlične predispozicije za razvoj ruralnog turizma koje se sreću kod malog broja planina u našoj zemlji. Stara planina je veoma bogata biološkom, geološkom i kulturnom baštinom. Postizanje vidljivih ekonomskih efekata zahteva niz aktivnosti, podršku i kontinuirano praćenje svih nivoa vlasti. Pružanjem turističkih usluga domaćim i stranim turistima ostvaruju se značajni prihodi. Ostvarivanje pozitivnih rezultata turističke privrede zavisi od njene sposobnosti da zadovolji potrebe posetilaca u izabranim turističkim destinacijama. Stoga, cilj rada je da se predstavi strategijska pozicija ruralnog turizma kao značajne delatnosti u okviru turizma. U cilju što boljeg razvoja ruralnog turizma neophodno je shvatanje značaja jačeg ekonomskog razvoja ruralnih sredina, tako da ovaj rad na temeljan način izučava mišljenje ispitanika na osnovu ANOVA metode i pokušava da ukaže na strateške pravce razvoja ruralnog turizma na Staroj planini.
\end{abstract}

Ključne reči: Stara planina, strategijsko pozicioniranje, turizam, ruralni turizam.

4 Dr Gordana Petrović, Nastavnik geografije, Osnovna škola “Živadinka Divac” Kragujevac, Kralja Milutina bb, 34000, Kragujevac, Telefon: +381 64 1892281, E-mail: milicakg98@yahoo.com

5 Dr Mlađan Maksimović, Nezavisni istraživač, Bulevar dr Zorana Đinđića bb, 19000, Zaječar, Telefon: +38164 1479793, E-mail: mladjan21@yahoo.com

6 Doc. dr Darjan Karabašević, Fakultet za primenjeni menadžment, ekonomiju i finansije, Univerzitet "Privredna akademija" u Novom Sadu, Jevrejska 24, 11000, Beograd, Telefon: +381 60 3383333, E-mail: darjankarabasevic@gmail.com

EP 2017 (64) 2 (601-617) 